


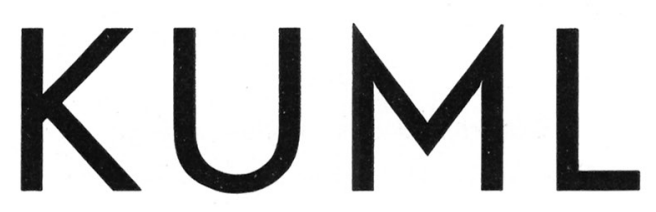

\section{ÅRBOG FOR JYSK ARKÆOLOGISK SELSKAB 1957}

With Summaries in English Mit deutschen Zusammenfassungen 
Forside:

Restaurering af jættestue i Tustrup

Restoration of passage grave at Tustrup

Redaltion:

P. V. G L O B

Copyright 1958

by

Jysk Arkceologisk Selskab

Printed in Denmark

by

Aarhuus Stiftsbogtrykkerie A/S

Clichéer:

Hammerschmidt - Århus 


\section{N D H O L D}

Johannes Brøndsted: Erik Westerby $\ldots \ldots \ldots \ldots \ldots \ldots \ldots \ldots \ldots \ldots \ldots \ldots \ldots$

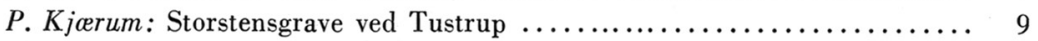

Knud A. Larsen: Stenalderhuse på Knardrup Galgebakke ............ 24

Bent Sylvest: En sværdskede fra ældre bronzealder ................ 44

C. J. Becker: F $\varnothing$ rromersk jernaldergrav fra Try skole i Vendsyssel ....... 49

Ad. Stender-Petersen: Jordanes' beretning om Goternes udvandring ..... 68

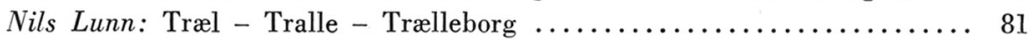

Torkild Ramskou: Stavgård og bautavi $\ldots \ldots \ldots \ldots \ldots \ldots \ldots \ldots \ldots . \ldots . \ldots 6$

Johannes Nicolaisen: Slaveri hos Tuaregerne i Sahara $\ldots \ldots \ldots \ldots \ldots . . \ldots 1$

P. V. Glob: Slangeofre i Bahrains oldtidshovedstad ................. 114

T. G. Bibby: Bahrains oldtidshovedstad gennem 4000 år ............ 128

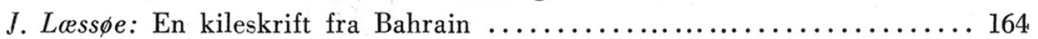

P. V. Glob: Oldtidsfund i Qatar .......................... 167

Jysk Arkæologisk Selskab ................................ 179

V. Gordon Childe: Tilbageblik .............................. 180

Ole Klindt-Jensen: Seán P. Ó Ríordáin ........................ 188

Stuart Piggott: V. Gordon Childe og Seán Ó Ríordáin................. 190

Wilhelm Holmqvist: Nils Åberg ............................. 192

\section{CONTENTS}

Johannes Brøndsted: Erik Westerby $\ldots \ldots \ldots \ldots \ldots \ldots \ldots \ldots \ldots \ldots, 8$

P. Kjærum: Megalithic tombs at Tustrup ...................... 22

Knud A. Larsen: Stone-Age houses on Knardrup Gallows Hill .......... 41

Bent Sylvest: A scabbard from the Early Bronze Age ............... 48

C. J. Becker: Ein vorrömisches Grab von Try, Amt Hjørring ........... 64

Ad. Stender-Petersen: Jordanes' Bericht von der Auswanderung der Goten.. 76

Nils Lunn: Træl - Tralle - Trælleborg ........................ 84

Torkild Ramskou: Stave-yard and sacred enclosure ................ 89

Johannes Nicolaisen: Slavery among the Tuareg in the Sahara ......... 107

P. V. Glob: Snake sacrifices in Bahrain's ancient capital .............. 125

T. G. Bibby: The hundred-meter section ........................ 152

J. Lassøe: A cuneiform inscription from the island of Bahrain .......... 165

P. V. Glob: Prehistoric discoveries in Qatar ...................... 175

Jysk Arkæologisk Selskab ................................. 179

V. Gordon Childe: Retrospect .............................. 180

Ole Klindt-Jensen: Seán P. Ó Ríordáin ........................ 188

Stuart Piggott: V. Gordon Childe and Seán P. Ó Ríordáin ............ 190

Wilhelm Holmqvist: Nils Åberg ............................. 194. 


\title{
STAVGÅRD OG BAUTAVI
}

\author{
Af TORKILD RAMSKOU
}

Før man begyndte at grave i Jelling-højene, var problemerne om dem meget enklere. Man havde to høje, de to runesten og kirken, foruden de få skriftlige

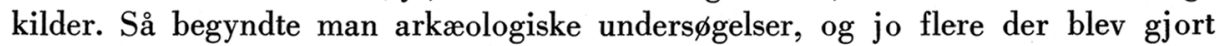
af dem, jo flere problemer dukkede der op. Og med dem selvfølgelig tolkningsfors $\varnothing$ gene. Men lad os lige så godt indrømme det først som sidst: præmisserne er for utilstrækkelige til at man kan nå en skud- og vandtæt konklusion.

Men man kan ikke blive derfra alligevel. Det kunde jo være, at man havde fundet lige netop det nye stof der, føjet til det foreliggende, inspirerer til en anden og måske mere plausibel forklaring end de hidtil fremkomne.

Det der gav stødet til de følgende reflexioner er Gotlands-lovens kap. 4: »... Der er nu dernæst, at blót og fordums sæd som hedendom følger er mennesker meget forbudt. Ingen må påkalde hverken holt (:skov) eller høje eller hedningeguder, hverken vier eller stavgårde ... «?

Vier eller stavgårde. Hvad er det?

Et vi er ifølge Jonsons Oldnordisk Ordbog: et helligt sted, et offersted, et fredhelligt sted. Og stauragarðr er et stavgærde, et plankeværk. Det ser altså ud, som en stavgård godt kan være et vi, hvorimod et vi kan omfatte noget mere.

Men det var stavgården, plankeværket.

I den oldnordiske litteratur er der ikke så få steder, der viser at fædrekult har været meget almindelig i vikingetidens Skandinavien. Dels har den været knyttet direkte til gravene, dels har man kunnet have billedstøtter af forfædrene på et vilkårligt valgt sted, dog vel som oftest $\mathrm{i}$ nærheden af gården. Et godt eksempel herpå er fortællingen i Færeyinga Saga om Hakon Jarls besøg i sit kulthus, hvor han havde en billedst $\varnothing$ tte af Thorgerd Helgebrud, der var en af hans berømte forfædre, eller rettere formødre. Billedstøtten stod $i$ et lille hus, der var omgivet af et plankeværk. - $\mathrm{Og}$ i fortællingen om Thorleif Jarleskjald omtales der flere billeder. Foruden Thorgerd var der en støtte af hendes søster Irpa og dennes mand Helge. Her er der altså tale om et helt forfædretempel.

Den så ofte citerede Ibn Fadhlan's beskrivelse af Ruslands-vikingerne kan også drages ind i billedet. Den citeres her efter en norsk oversættelse: »... med det samme skipene deres (varægernes) var kommet til denne ankerplassen, gikk hver av dem i land, hadde med seg brød, kjøtt, løk, melk og nabid (en rusdrikk) og gikk bort til en høy, oppreist trestøtte med et ansikt som ser ud som et menneskeansikt. Rundt omkring den er der små figurer, og bakom disse figurene høye trest $\varnothing$ tter som er satt ned i jorden... Derpå legger han det han har med sig foran støtten..." 

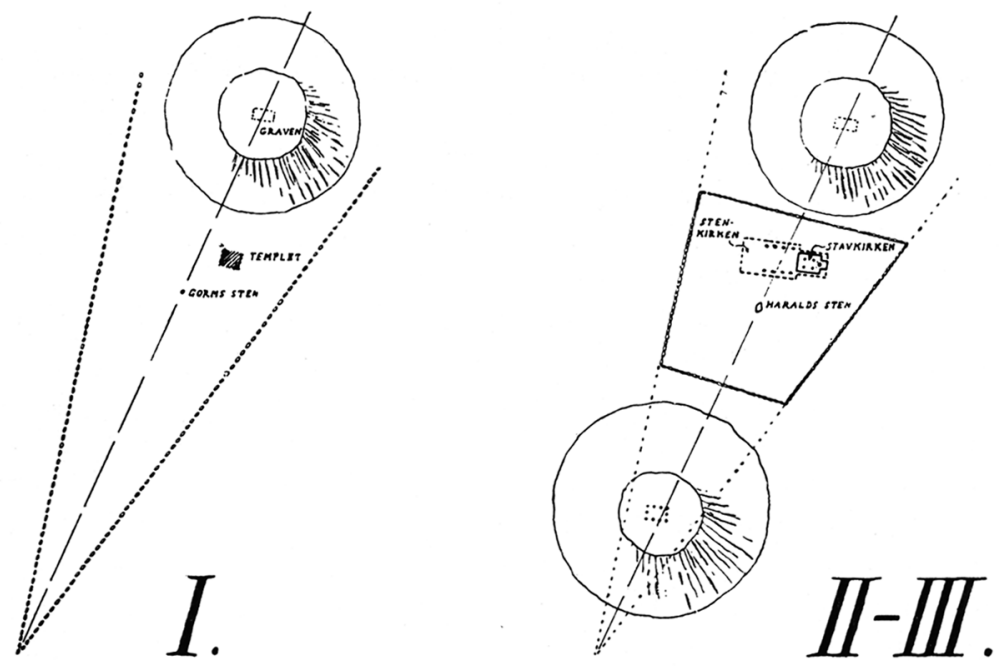

Fig. 1. Jellingmonumenternes hovedperioder: I, Gorms anlæg; II, Haralds kristne anlæg; III, stavkirken erstattet med stenkirken. Efter Ejnar Dyggve.

The main periods of the Jelling monument: I, Gorm's layout; II, Harald's Christian layout; III, the stave church replaced by the stone church. After Dyggve.

Her har vi altså beskrivelsen af en kultplads, der omfatter 1: en stor, dominerende st $\varnothing$ tte i midten. 2: mange mindre st $\varnothing$ tter omkring den st $\varnothing$ rste og endelig 3: træstolper rejst omkring figurerne, altså en slags gærde.

Er det for meget at tro, at Ibn Fadhlan har givet os den hidtil eneste kendte beskrivelse af en stavgård? Næppe.

Her stod støtterne altså i fri luft i en indhegning. Ganske vist siges det ikke om det er egentlige gudest $\varnothing$ tter, eller det er forfædrest $\varnothing$ tter. Men det gøre mindre til sagen. Vigtigst er, at kultpladsen synes at være en stavgård. $\mathrm{Og}$ så kan vi lige minde om, at Hakon Jarls hus med forfædrestøtten også stod i en stavgård.

$\mathrm{Vi}$ vender tilbage til Jelling.

Senest er udgravningerne beskrevet og fortolket af Ejnar Dyggve i »Jellingkongernes Mindesmærker", Kolding 1956.

Nordhøjens gravkammer har længe været kendt. Det er Dyggves nye udgravninger, der virkelig har givet os noget at spekulere på. Her er i al korthed, hvad der fandtes eller konstateredes: Intet gravkammer i sydhøjen, der var tom, bortset fra en teltagtig trækonstruktion, hvis sider dannede en vinkel med hinanden. Rester af et lignende "telt « fandtes i Nordhøjen. Udgraveren har aldrig lagt særlig vægt på disse trækonstruktioner i sine publikationer af unders $\varnothing$ gelserne, og dog forekommer de betydningsfulde for forståelsen af hele anlægget. - Den næste mærkværdige ting, der fandtes, var de to lange rækker bautasten, der også danner vinkel med hinanden ved sydh $\varnothing$ jen. Vinklens ben omslutter nordh $\varnothing j e n$, 
hvis centrum ligger $\mathrm{i}$ vinklens halveringslinie. Udgraveren tolker denne trekantede plads som et vi, og sikkert med rette. - Endelig er der under den romanske kirke fundet rester af en ældre stavkirke, og under den igen spor af en endnu ældre bygning, der måske som foreslået har været et hedensk kulthus. Endelig konstateredes det, at den store runesten stadig står på sin oprindelige plads.

Om disse elementers tidsmæssige rækkefølge synes så meget at være sikkert. Den lille runesten lader formode, at Gorm har overlevet Thyra. Man må da gå ud fra, at han har ladet hende begrave $\mathrm{i}$ nordhøjen, og at han $\mathrm{i}$ forbindelse med den har rejst de to rækker bautasten.

Slutter man ud fra forholdene i sydhøjen, er det nok ikke forkert at antage, at nordh $\varnothing j$ jen har været påbegyndt længe før Thyras d $\varnothing \mathrm{d}$. Men forberedelserne til en dronnings begravelse gøres ikke på få dage, selv om gravhøjen skulde være omtrent færdig. - Vi kender andre steder fra beretninger om foreløbige begravelser indtil alt er rede til den egentlige bisættelse. Vi kan tro, at nordh $\varnothing$ jens "telt" har været let tilgængeligt fra højsiden, så man uden besvær kunde anlægge en forel $\varnothing$ big begravelse i højfylden indenfor »teltet«s rammer. Hvorfor den skulde ligge her, vender vi tilbage til. Den kan have rummet Thyras og måske siden Gorms lig før de tos fællesgrav blev endelig lukket og højen færdigbygget af sønnen Harald.

Og nu det kæmpemæssige bautavi. Det kan tvangfrit fortolkes som en kolossal »stavgård ", sat af uforgængelige sten, så den kunde danne en evig og værdig ramme om den kult, der knyttedes til Thyras og Gorms grave. Jævnfør Gotlandslovens forbud mod tilbedelse af $h \varnothing j e$ og stavgårde. De egentlige kulthandlinger kan have udspillet sig i den ældre bygning under de to kirker.

Sydhøjen. En ting er sikker: Sydhøjen er først påbegyndt et vist åremål efter at stavgården af sten var rejst, eller viet, skal vi måske hellere blive ved at kalde det. Det er som om det ord passer bedre til det store, kongelige anlæg. - Harald skulde jo også have en grav. Intet vilde være mere naturligt, end om han $\varnothing$ nskede, at den skulde ligge indenfor viets rammer. $\mathrm{Og}$ skulde han have en gravh $\varnothing \mathrm{j}$, der var mindre end Gorms og Tyras? Nej, ihvertfald skulde den være lige så stor. Stavgårdens midte var optaget dels af Gorms runesten, dels af kulthuset. Det eneste sted Harald altså kunde lægge sin egen gravh $\varnothing \mathrm{j}$ var da i viets vinkelspids, og det gjorde han. Med centrum i vinklens halveringslinie danner den en kontravægt mod nordh $\varnothing j e n$, og med tidens sans for det symmetriske anbragte han derefter den store runesten præcist midt mellem de to høje.

Er det tænkeligt, at Harald har opført eller påbegyndt sin egen høj? Javist, vi har jo flere beretninger om stormænd, der vilde være sikre på, at deres grav blev som de $\varnothing$ nskede og derfor selv byggede h $\varnothing$ jen. Og hvem andre end Harald skulde have bygget sydhøjen? Gorm? Næppe, så var han nok også blevet begravet $\mathrm{i}$ den.

Det har været fremsat, at kun en kristen kan have bygget sydhøjen, da viet derved blev фdelagt. Det forekommer dog mere sandsynligt, at den er anlagt af en mand der netop фnskede intim tilknytning til kultområdet. Det vises jo af højens og den store runestens nøje gennemtænkte og udmålte placering. Og endnu en ting viser højbyggerens store fortrolighed med viet. Thi det omatle »telt« er med flid anbragt så vinkelspidsen falder i højens centrum, og vinklens 
størrelse er lig viets. Øjensynligt har det været betydningsfuldt, at de to vinkler blev lige store. Kristendommen kan ikke have tynget højbyggeren svært.

Det fremgår ikke klart af publikationerne, men det ser ud som om »teltets" brede ende har været let tilgængeligt fra siden af den halvfærdige $h \varnothing j$, så Harald har sørget ikke blot for sin gravh $\varnothing$, men også for at den midlertidige grav, der skulde tages $i$ brug under forberedelserne til gravøllet, kunde anlægges indenfor teltets vinkel. Kan »teltet« tolkes anderledes? Næppe. Grundridset er jo som det store vi, så det kan siges at være en provisorisk stavgård.

Men hvis Harald trods sin nyerhvervede kristentro alligevel regnede med at blive højlagt efter gammel skik, tog han fejl. Der blev ikke noget af. Man kan tænke sig, at det har præsterne sørget for. Det var jo god propaganda, hvis kongen havde "ønsket" en kristen begravelse. Man kan også udmærket tænke sig, at det er præsterne, der har foranlediget viet nedlagt og en kirke bygget på kulthusets plads. Men det er rene formodninger, og af dem er der plads til mange.

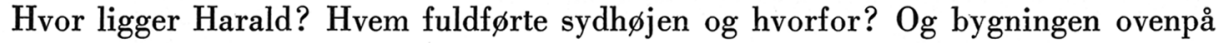
sydhøjen. Et mindekapel for Harald? Hans begravelse? Hvem ved. Det er spørgsmål, der falder udenfor i denne forbindelse. - Her gjaldt det blot om at sandsynliggøre, at viet er en kongelig stavgård; at Harald har bygget sydhøjen til sig selv, for at være indenfor viet, og at »teltene« i begge høje har været rammer om de foreløbige begravelser. $\mathrm{Og}$ er man ikke enige heri, kan det måske give st $\varnothing$ det til at nye og forbedrede fortolkninger ser dagens lys.

\section{SUMMARY}

\section{Stave-yard and Sacred Enclosure.}

The monuments at Jelling, and the results of the investigations in and around them, have last been described by the actual excavator, Ejnar Dyggve. He expresses the opinion that the south tumulus can only have been erected by someone who wished to destroy the monument as it existed at that time, consisting of the north tumulus and the monolith enclosure.

The results of the excavations would rather appear to show that the south tumulus was erected by someone who wished to be associated as closely as possible with the enclosure and the north tumulus, by presumably Harald, the son of Gorm and Thyra. The facts which clearly support this view are the exact positioning of the south tumulus with its centre point on the line bisecting the V-shaped enclosure, and the position of the larger rune-stone exactly halfway between the centre points of the two tumuli. But the circumstance which shows most clearly the familiarity which the builder of the south tumulus had with the sacred enclosure is that the "wooden tent-like construction" found inside the tumulus has walls at the same angle to each other as the monolith walls of the enclosure, and that the angle of these walls, if projected, would cut each other in the centre of the tumulus.

In brief, the builder of the south tumulus possessed exact knowledge of the construction of the enclosure and wished to be laid to rest himself within its bounds; and he therefore chose the only vacant place possible for his tumulus. The north tumulus, the old culthouse and the large rune-stone occupied the one end of the enclosure, only the narrow acute-angle end remained free, and there the tumulus was in consequence erected. 
The enclosure itself must have been a royal counterpart of what the Gotland Law calls a "stave-yard" (stavgård), erected as a frame around an ancestral cult. The "wooden tent-like constructions" found within both tumuli may have served as temporary burialplaces before the actual tumuli were built. - And if we cannot agree on these interpretations, they may at least perhaps serve to provide the impetus which can result in new and improved interpretations coming to light.

Thorkild Ramskou.

\section{I T T E R A T U R}

Guterlov og Gutersaga. Paa dansk ved Lis Jacobsen, f. Rubin. Skrifter udgivne af Selskabet til historiske Kildeskrifters Oversættelse. Syvende Række. 6. København 1910. - Birkeli, Huskult og hinsidestro. Birkeli, Fedrekult $i$ Norge. - Birkeland, Harris, Nordens Historie i Middelalderen efter arabiske Kilder.

- Dyggve, Ejnar, Jellingekongernes Mindesmarker, Kolding 1956. 